\title{
Paid Family Leave to Strengthen the STEM Workforce
}

\section{Addressed to: The Subcommittee on Worker and Family Support, Committee on Ways and Means, United States House of Representatives}

\author{
H. Alex Hsain ${ }^{1,4}$, Ryan Tam²,4, Ishita Kamboj¹,4, Hanna \\ Berman $^{3,4}$, and Ryan Dudek ${ }^{2,4}$
}

${ }^{1}$ North Carolina State University, College of Engineering, Materials Science and Engineering, Raleigh, NC ${ }^{2}$ North Carolina State University, College of Engineering, Chemical and Biomolecular Engineering, Raleigh, NC ${ }^{3}$ North Carolina State University, College of Veterinary Medicine, Population Health and Pathobiology, Raleigh, NC

${ }^{4}$ Science Policy Pack at NC State, Raleigh, NC

http://doi.org/10.38126/ISPG170207

Corresponding author: hahsain@ncsu.edu

Keywords: paid family leave; STEM workforce; women in STEM; gender equality

Executive Summary: In the United States many women in science, technology, engineering, and mathematics (STEM) leave their careers after becoming a parent. Attrition is simultaneously occurring with workforce shortages in STEM with two million jobs potentially unfilled by 2025 . While there has been an increase in STEM recruitment of women over recent decades, policies aimed at decreasing departure of women in STEM have not been prioritized. The Family and Medical Leave Act of 1993 (FMLA) guarantees workers up to 12 weeks of unpaid, job-protected leave, but has not shown to increase workforce attachment of new mothers. Instead, studies suggest that short durations of paid leave (6-12 weeks) increase workforce attachment. Medical consensus suggests that a leave of 26 weeks is necessary for maternal health and a leave of 40 weeks is optimal for infant well-being. Coupled with recently introduced paid parental leave legislation in Congress, we recommend timely action to decrease the departure of women from the workforce and to strengthen gender equality in STEM. We recommend instituting 12 weeks of federal paid family leave (PFL) under the recently introduced national family leave insurance program in the Family and Medical Insurance Leave Act (FAMILY Act; S. 463/H.R. 1185).

\section{Statement of issue}

Parenthood is a significant barrier to US women's participation in the science, technology, engineering, and mathematics (STEM) workforce. While women make up $50 \%$ of the U.S. collegeeducated workforce, only $35 \%$ graduate with STEM baccalaureates and $28 \%$ go on to join the STEM workforce (NSF 2018; U.S. Department of Education 2017). The small percentage of women who do join the STEM workforce are later deterred due to the disproportionate burden placed on them during parenthood. A recent study has shown that over $40 \%$ of women with full-time jobs in STEM leave the sector or begin part-time work after having their first child (Figure 1) (Cech, Blair-Loy 2019, 4183). By contrast, only 23\% of 
new fathers leave or reduce hours. This phenomenon, which describes the loss of women from the STEM workforce, is referred to as the "leaky pipeline." Pregnancy and parenting disproportionately affect women and contribute to decreased participation in the STEM labor force (Shauman and Xie 2013, 53-56; Correll 2004, 93113; Cech et al. 2011, 641-666).

Concurrently, the growth of STEM-related jobs is outpacing the number of trained workers. The National Association of Manufacturing predicts the US will need to fill $\sim 4.5$ million STEM jobs by 2025 . Yet, up to $\mathbf{2}$ million unfilled jobs may remain due to the lack of qualified candidates (Emerson, 2018). The US has been an established leader in STEM since the Industrial Revolution, but it will need to strategically invest in its workforce to secure its global STEM leadership. Preventing the departure of women from the STEM workforce by investing in parental leave policies could help mitigate potential shortages in STEM-related jobs.

While the US has invested heavily in programs recruiting women and minorities into STEM careers, little has been done to address the attrition of women. A meta-study conducted in 2013 reveals that women in STEM careers are over five times more likely to exit the STEM field than women in other professional disciplines (Glass et al. $2013,723-56)$. This is due to a variety of factors but is heavily influenced by planning to have children (Glass et al. 2013, 723-56). For example, the transition from early to mid-career in STEM occurs during the last few years (mid-thirties) of a woman's ability to have a non-geriatric pregnancy (Bellieni 2016, 104-7).

In order to meet the high demand anticipated for STEM workers in the coming decades, the United States will need to consider strategies for not only recruiting but also retaining women in the STEM workforce after they become parents. Parental leave policies will need to be considered. This memo evaluates the political, economic, and medical factors concerning paid family leave (PFL) policies and their effect on labor force attachment of women and presents policy recommendations for implementing the first PFL policy in the United States.

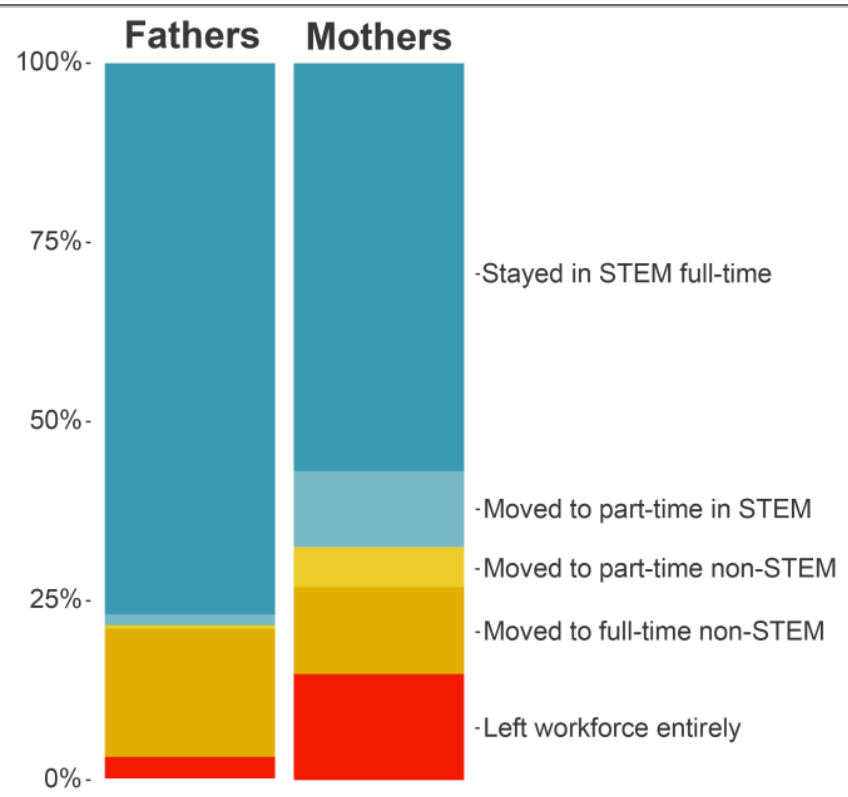

Figure 1: Parenting and STEM careers. New mothers leave STEM careers at a higher rate than new fathers, indicates an 8-year-long study of 841 scientists who became new parents between 2003 and 2006 (Cech 2019; Figure adapted from Else 2019).

\section{i. Political and legal status}

The US is the only member of the 35 Organization for Economic Cooperation and Development (OECD) countries that does not offer PFL to new mothers, and one of only eight that do not provide leave (paid or unpaid) to fathers (Donovan 2019). The average duration of parental leave in OECD countries is 57 weeks, while the average paid leave is 41 weeks (Donovan 2019; Blau and Kahn 2013, 251-56). In these countries, parental leave reforms have shown to increase women's economic outcomes, increase child health, and reduce infant mortality (Nandi et al. 2018, 434-71). Often, nationally mandated social insurance funds dictate the terms of PFL in OECD countries (Bipartisan Policy Center 2020). For example, Germany's Parental Allowances and Parental Leave Act (BGBI I.S. 2748) allows PFL of up to 14 months (Bipartisan Policy Center 2020).

Currently, there is no US federal mandate for PFL. The Family and Medical Leave Act (FMLA) of 1993 guarantees qualified workers up to 12 weeks of unpaid, job-protected leave per year for medical reasons including childbirth. Department of Labor estimates from 2012 show that $\sim 60 \%$ of US 
workers were covered under FMLA ${ }^{1}$, but $46 \%$ of those eligible were not able to afford to take unpaid leave (Klerman, Daley, and Pozniak 2012). Additionally, a Bureau of Labor Statistics survey showed that only $16 \%$ of private-industry employees had access to PFL through their employers (Donovan 2019).

Previous research suggests FMLA has had little impact on women's labor-force attachment (Blau and Kahn 2013, 251-56; Waldfogel 1999, 281-302; Han, Ruhn, and Waldfogel 2009, 29-54). In contrast, new studies show that short durations (6-12 weeks) of paid leave increase the labor force attachment of women who would otherwise leave work temporarily after becoming a parent (Byker 2016, 242-46; Ruhm 1998, 285317).

Few states have PFL laws in place. Currently only five states (California, Hawaii, New Jersey, New York, and Rhode Island) and Puerto Rico have State Disability Insurance (SDI) that provides between 6-12 weeks of paid leave with partial wages for workers with temporary disability, including pregnancy (Klerman, Daley, and Pozniak 2012). According to a study from the March of Dimes Center for Social Science Research, states that have implemented PFL policies have reduced the departure of female employees by $20 \%$ in their first year after childbirth and up to a $\mathbf{5 0 \%}$ reduction after five years (Jones and Wilcher 2019). Other studies have also shown that access to PFL increases workforce attachment, the likelihood that a person will return to the workforce, as well as the likelihood of maintaining pre-leave wages and increased long-term earning potential (Appelbaum and Milkman 2011).

While the Trump administration has vocalized its support of PFL, there has been no progress for private-sector workers on the issue to date. Legislative activity of the 116th Congress has mainly focused on increasing access to PFL while decreasing the associated costs to employers. Congress has proposed the establishment of a national family leave insurance program as proposed in the Family and Medical Insurance
Leave Act (FAMILY Act; S. 463/H.R. 1185) (U.S. Congress 2020). This Act would provide up to 12 weeks of partial income and extend coverage to include workers in companies of all sizes, not just those currently covered by FMLA.

\section{ii. Scientific and medical consensus}

It is important to recognize that the decision to have FMLA provide 12 weeks of unpaid leave has no scientific basis, but rather is based on political consensus. Twenty-six weeks of leave may meet maternal needs, whereas 40 weeks of paid leave could provide the greatest reduction in infant mortality (Schulte et al. 2017). Early backers of the FMLA called for six months of paid leave; this form was vetoed twice by President George H.W. Bush and took nearly ten years to be approved in its current form of 12 weeks unpaid leave. The original six-month recommendation is buttressed by postpartum recovery studies showing maternal physical and emotional issues persisting beyond six months after childbirth, even though women under-report these issues (Thompson et al. 2002, 83-94). Additionally, studies have shown that maternal employment in the first year of life negatively impacts cognitive development in children with effects that persist up to 8 years, while leaves of 6 to 12 months were associated with better developmental outcomes (Gaston, Edwards, and Tober 2015, 230-51). Developing children's brains are primarily influenced by attachment relationships with their mother and nutritional factors obtained through breastfeeding in the first year of life (Belfort 2017, 459). Thus, any disruption to parental attachment, such as early detachment due to the mother working, can have long-term effects on cognitive and behavioral development.

For example, an analysis comparing family leave between OECD countries, with an average of 18 weeks of job-protected PFL, predicts that a 10week extension of job-protected PFL reduces child mortality rates by $3 \%$ (Bipartisan Policy Center 2020). This may be influenced by health promoting behaviors such as breastfeeding, immunization, and utilization of health services due to and in combination with increased pay. Mothers may also

\footnotetext{
${ }^{1}$ FMLA eligibility criteria include: 1) the employee must have been employed with the company for 12 months, 2) the employee must have worked at least 1,250 hours during the 12 months prior to the start of FMLA leave, and 3) the employer is one who employs 50 or more employees within a 75 -mile radius of the worksite.
} 
experience fewer symptoms of depression after the age of fifty if given more generous PFL at the time of childbirth. However, studies highlighting the effect of PFL on maternal health are limited (Bipartisan Policy Center 2020). In support of these and other findings, the International Labor Organization (ILO) views maternity protection as a "fundamental human right" and recommends no less than 18 weeks of leave (Gilchrist, Addati, and Cassirer 2014, 120). This growing body of evidence suggests that a leave period of 12 weeks is grossly insufficient to ensure both maternal and infant wellbeing.

\section{iii. Economic considerations}

Historically, one of the main roadblocks for implementing US PFL policies has been the perceived financial cost to employers. However, studies recognize that businesses can gain more from retaining workers with firm-specific knowledge and skills and by minimizing costs of hiring and training new employees (U.S. Congress 2019; Council of Economic Advisors 2014). A survey of California employers with PFL policies in place found that less than $10 \%$ of employers reported adverse effects of profitability, turnover, and morale (Appelbaum and Milkman 2011).

Paid leave is also likely to have economy-wide benefits. Paid leave has a greater effect on labor force participation rates of women than of men and could potentially increase GDP by $5 \%$ in the US by equalizing labor force participation (Gault et al. 2014, 22-34). Additionally, paid leave has the potential to reduce government spending on public assistance. Studies of unpaid FMLA leave show that $10 \%$ of eligible workers receiving some or no pay sought public assistance (Gault et al. 2014, 22-34). Thus, offering paid leave can improve productivity, morale and labor force participation while saving costs and increasing economic growth.

The economics of paid leave have also changed over the years as the concept of a nuclear family has evolved. Family structures have significantly changed in the past two decades, and families increasingly depend on women's earnings (Joint Economic Committee 2014). In 2013, almost two-thirds of families relied entirely or partially on a mother's income, and 45 million children lived with a mother in the labor force (Joint Economic Committee 2014). As a result, working families lose an estimated $\$ 20.6$ billion in wages each year due to a lack of access to paid family and medical leave (National Partnership for Women and Families 2019).

\section{Policy options}

\section{i. Option A - 26 weeks of paid leave}

\section{Advantages}

- Meets basic maternal wellbeing requirements, allows mothers to breastfeed, bond, and supervise their children while fully recovering from childbirth (Schulte et al. 2017; Thompson et al. 2002, 83-94; Gaston, Edwards, and Tober 2015, 230-51);

- Lessens financial strains on American families who could not otherwise take unpaid leave and allows mothers to ease back into the workforce (Joint Economic Committee 2014; (National Partnership for Women and Families 2019);

- Duration predicts positive outcomes for women's labor force attachment (Byker 2016, 242-46; Ruhm 1998, 285-317; Jones and Wilcher 2019).

\section{Disadvantages}

- Employers would be required to make moderate to large payroll changes. Based on estimates in the FAMILY Act, employee payroll deductions to pay for 26 weeks PFL could amount to $\$ 4.00$ per week (approximately $0.4 \%$ of income) for a typical worker (National Partnership for Women and Families 2019);

- Employers would be required to make organizational changes to double the amount of leave time for workers (currently 12 weeks through FMLA). 
ii. Option $B-12$ weeks of paid leave

\section{Advantages}

- Twelve weeks duration has been shown to be successful in improving the likelihood of mothers returning to work after childbirth (Byker 2016, 242-46; Ruhm 1998, 285317; (Jones and Wilcher 2019);

- Currently is the same leave duration as established by FMLA; therefore, this policy would benefit employers who may not be equipped to find longer duration of temporary workers;

- Compared to Option A (26 weeks PFL), US employers instituting 12 weeks PFL will only need to make small or moderate changes to employee payroll deductions (less than $\$ 2.00$ per week for a typical worker if enacted through the FAMILY Act) (National Partnership for Women and Families 2019);

- If enacted through the FAMILY Act, all workers would have access to PFL policies, and not just those at larger companies.

\section{Disadvantages}

- Does not meet family health requirements for either the mother or the infant (Schulte et al. 2017; Thompson et al. 2002, 83-94; Gaston, Edwards, and Tober 2015, 230-51).

\section{iii. No change to current leave policy}

\section{Advantages}

- Employers will not be required to make any changes to their current payroll collections. As a result, employees will have more take-home pay as they are not contributing to PFL insurance.

\section{Disadvantages}

- If FMLA remains as the federal legislation regulating family leave, women will continue to be pushed out of the STEM workforce, further exacerbating gender disparity in the US and greatly hurting our competitive STEM workforce (Cech, Blair-Loy 2019, 4183; Blau and Kahn 2013, 251-56; Waldfogel 1999, 281302; Han, Ruhn, and Waldfogel 2009, 29-54).

- Women unable to take unpaid leave will return to work prematurely, harming both the mother and child (Appelbaum and Milkman 2011).

- Women who take less than 12 weeks will have a greater risk for developing postpartum complications and depression (Gaston, Edwards, and Tober 2015, 230-51).

- A staggering number of infants in the US will continue to experience delayed cognitive and behavioral development due to inadequate care and bonding (Belfort 2017, 459).

\section{Policy recommendations}

We recommend an incremental approach and compromise with 12 weeks of PFL (Option B) under new proposed legislation, the Family and Medical Insurance Leave Act (FAMILY Act; S. 463/H.R. 1185). While Option $A$ is in best agreement with medical consensus, the proposal of 26 weeks of PFL is unlikely to receive sufficient political support from those who believe PFL would pose significant financial burdens to US employers. We advise instituting PFL under the new FAMILY Act legislation as current FMLA legislation does not cover $40 \%$ of workers in the US due to stringent eligibility criteria. The FAMILY Act would ensure coverage for all workers, especially those in STEM fields who are more likely to be susceptible to workforce attrition. Given that studies have shown that short duration paid leave is successful in increasing labor force attachments in women, this option is predicted to decrease national attrition rates of women in the STEM workforce and strengthen US gender equality.

\section{References}

Appelbaum, Eileen, Milkman, Ruth. 2011. "Leaves That Pay: Employer and Worker Experiences with Paid Family Leave in California," Center for Economic and Policy Research. Accessed June 13, 2020. http://www.cepr.net/documents/publications/p aid-family-leave-1-2011.pdf
Appelbaum, Elieen, and Ruth Milkman. 2011. "Paid Family Leave Pays Off in California," Harvard Business Review, January 19, 2011. http://blogs.hbr.org/2011/01/paid-familyleave-pays-off-in/. 
Bellieni, Carlo. 2016. "The Best Age for Pregnancy and Undue Pressures." Journal of Family \& Reproductive Health 10 (3): 104-7.

BipBipartisan Policy Center. 2020. "Paid Family Leave Across OECD Countries." Accessed June 13, 2020. https://bipartisanpolicy.org/explainer/paidfamily-leave-across-oecd countries/\#: :text=Provides\%20paid\%2C\%20jo b\%2Dprotected\%20leave\%20to\%20working\%2 0mothers $\% 20$ and $\% 20$ fathers, $100 \% 20$ percent $\%$ 20(Figure\%201).

BlaBlau, Francine D., and Lawrence M. Kahn. 2013. "Female Labor Supply: Why Is the United States Falling Behind?" The American Economic Review 103 (3): 251-56. https://doi.org/10.1257/aer.103.3.251

Brown Belfort, Mandy. 2017. "The Science of Breastfeeding and Brain Development." Breastfeeding Medicine: The Official Journal of the Academy of Breastfeeding Medicine 12 (8): 459-61. https://doi.org/10.1089/bfm.2017.0122

Byker, Tanya S. 2016. "Paid Parental Leave Laws in the United States: Does Short-Duration Leave Affect Women's Labor-Force Attachment?" The American Economic Review 106 (5): 242-46. https://doi.org/10.1257/aer.p20161118

Cech, Erin A. and Mary Blair-Loy. 2019. "The changing career trajectories of new parents in STEM." Proceedings of the National Academy of Sciences of the United States of America 116 (10): 4182-87 https://doi.org/10.1073/pnas.1810862116.

Cech, Erin, Brian Rubineau, Susan Silbey, and Caroll Seron. 2011."Professional role confidence and gendered persistence in engineering." American Sociological Review 76:641-666. https://doi.org/10.1177/0003122411420815

Correll, Shelley J. 2004. "Constraints into preferences: Gender, status, and emerging career aspirations." American Sociological Review 69:93-113.

Council of Economic Advisers. 2014. "The Economics of Paid and Unpaid Leave." Accessed June 13, 2020. http://www.whitehouse.gov/sites/default/files/ docs/leave report final.pdf

Donovan, Sarah A., 2019. "Paid Family Leave in the United States" Congressional Research Services (CRS). Accessed June 13, 2020. https://fas.org/sgp/crs/misc/R44835.pdf

Else, Holly. 2019. "Nearly half of US female scientists leave full-time science after first child." Nature News, February 19, 2019. https://www.nature.com/articles/d41586-01900611-1

Emerson. 2018. "Emerson Survey: 2 in 5 Americans Believe the STEM Worker Shortage is at Crisis Levels." Accessed June 13, 2020. https://www.emerson.com/enus/news/corporate/2018-stem-survey
Gaston, Anca, Sarah A. Edwards, and Jo Ann Tober. 2015. "Parental Leave and Child Care Arrangements During the First 12 Months of Life are Associated with Children's Development Five Years Later." International Journal of Child, Youth and Family Studies $\quad 6 \quad$ (2): 230-51. https://doi.org/10.18357/ijcyfs.62201513500

Gault, Barbara, Heidi Hartmann, Ariane Hegewisch, Jessica Milli, and Lindsey Reichlin. 2014. "Paid Parental Leave in the United States." Institute for Women's Policy Research (IWPR). https://iwpr.org/wpcontent/uploads/wpallimport/files/iwprexport/publications/B334Paid\%20Parental\%20Leave\%20in\%20the\%20U nited\%20States.pdf

Gilchrist, Katherine, Laura Addati, and Naomi Cassirer. 2014. "Maternity and paternity at work Law and practice across the world." International Labor Organization. ISBN: 978-92-2-128630-1.

Glass, Jennifer L., Sharon Sassler, Yael Levitte, and Katherine M. Michelmore. 2013. "What's So Special about STEM? A Comparison of Women's Retention in STEM and Professional Occupations." Social Forces; a Scientific Medium of Social Study and Interpretation 92 (2): 723-56. https://doi.org/10.1093/sf/sot092.

Han, Wen-Jui, Christopher Ruhn, and Jane Waldfogel. 2009. "Parental Leave Policies and Parents' Employment and Leave-Taking." Journal of Policy Analysis and Management: [the Journal of the Association for Public Policy Analysis and Management] 28 (1): 29-54. https://doi.org/10.1002/pam.20398

Joint Economic Committee. 2014. "Mother's Day 2014: An Update on the Importance of Mothers for Family Economic Security." Accessed June 13, 2020. http://www.jec.senate.gov/public/?a=Files.Serve \&File id=feebad86-1d0d-48ef-9f8f8b033325f29d

Jones, Kelley, Britni Wilcher. 2019. "Reducing Maternal Labor Market Detachment: A Role for Paid Family Leave". American University, Department of Economics, Working paper no. 2019-07. Accessed June 13, 2020. https://econpapers.repec.org/paper/amuwpape r/2019-07.htm

Klerman, Jacob Alex, Kelly Daley, Alyssa Pozniak. 2012; revised 2014. "Family and Medical Leave in 2012: Technical Report". US Department of Labor, Office of the Assistant Secretary for Policy. Accessed June 13 , 2020. https://www.dol.gov/sites/dolgov/files/OASP/l egacy/files/FMLA-2012-Technical-Report.pdf 
Nandi, Arijit, Deepa Jahagirdar, Michelle C. Dimitris, Jeremy A. Labrecque, Erin C. Strumpf, Jay S. Kaufman, Ilona Vincent, et al. 2018. "The Impact of Parental and Medical Leave Policies on Socioeconomic and Health Outcomes in OECD Countries: A Systematic Review of the Empirical Literature." The Milbank Quarterly $96 \quad$ (3): $434-71$. https://doi.org/10.1111/1468-0009.12340

National Partnership for Women and Families, 2019. "The Family And Medical Insurance Leave (FAMILY) Act fact sheet" Accessed June 13, 2020. https://www.nationalpartnership.org/ourwork/resources/economic-justice/paidleave/family-act-fact-sheet.pdf

NSF, "Science \& Engineering Indicators." 2018. https://nsf.gov/statistics/2018/nsb20181/

Ruhm, Christopher J. 1998. "The Economic Consequences of Parental Leave Mandates: Lessons from Europe." The Quarterly Journal of Economics 113 (1): 285317.

Schulte, Brigid, Alieza Durana, Brian Stout, Jonathan Moyer. 2017. "Paid Family Leave: How much time is enough?" Better Life Labs, New America, June 16, 2017. Accessed June 13, 2020. https://www.newamerica.org/better-lifelab/reports/paid-family-leave-how-much-timeenough/

Shauman, Kimberlee A. and Yu Xie. 2013. "Women in Science: Career Processes and Outcomes." (Harvard University Press, Cambridge, MA). ISBN13: 978-0674018594
Thompson, Jane F., Christine L. Roberts, Marian Currie, and David A. Ellwood. 2002. "Prevalence and Persistence of Health Problems after Childbirth: Associations with Parity and Method of Birth." $\begin{array}{lll}\text { Birth } & 29 & \text { (2): }\end{array}$ https://doi.org/10.1046/i.1523536x.2002.00167.x

U.S. Congress. House. 2020. Family and Medical Insurance Leave Act or the FAMILY Act, H.R.1185, 116th Cong., 1st sess. Introduced in House Feb. 13, 2020. https://www.congress.gov/bill/116thcongress/house-bill/1185

U.S. Congress. Senate. Joint Economics Committee. 2019. "The Economic Benefits of Paid Leave: Fact Sheet." Accessed June 13, 2020. https://www.jec.senate.gov/public/ cache/files/ 646d2340-dcd4-4614-ada9-be5b1c3f445c/jecfact-sheet---economic-benefits-of-paid-leave.pdf

U.S. Department of Education, National Center for Education Statistics. 2017. “Table 318.45: Number and percentage distribution of science, technology, engineering, and mathematics (STEM) degrees/certificates conferred by postsecondary institutions, by race/ethnicity, level of degree/certificate, and sex of student: 2008-09 through 2015-16." Digest of Education Statistics. Accessed June 13, 2020. https://nces.ed.gov/programs/digest/d16/table s/dt16 318.45.asp

Waldfogel, Jane. 1999. "The Impact of the Family and Medical Leave Act." Journal of Policy Analysis and Management 18 (2): 281-302.

H. Alex Hsain is a PhD graduate researcher and NSF Fellow in the Materials Science and Engineering Department at NC State University. She designs and studies electronic oxide capacitors at the atomic scale to be used in low-powered memory devices. Hsain serves as Co-President of the Science Policy Pack at NC State where she works alongside graduate students dedicated to increasing scientific participation in policy making.

Ryan Tam is a PhD candidate in the Chemical and Biomolecular Engineering Department at NC State University. His research focuses on engineering cell culture models of the mesolimbic pathway and epigenome modifying tools potentially useful in addiction studies. Ryan is also the Communications officer of Science Policy Pack at NC State where he aims to expand his professional science policy network and transition into a career in Biosecurity and Emerging Biotechnology Policy.

Ishita Kamboj is a PhD graduate researcher studying Materials Science and Engineering at NC State University. She develops deterministic, lithium-ion energy storage electrode architectures for simultaneous high energy and power density applications. Ishita is the Treasurer of the Science Policy Pack at NC State, where she collaborates with peers driven to engage meaningfully in science policy on both local and national levels.

Hanna Berman is a PhD candidate in the Comparative Biomedical Sciences program at NC State, with a concentration in Population Medicine. Her thesis research focuses on the vaginal microbiome and preterm birth, and she has also collaborated on projects regarding food safety and zoonotic disease. Hanna is a member of Science Policy Pack at NC State and is interested in health and science policy. 
Ryan B. Dudek is a PhD candidate in Chemical Engineering at NC State University focused on reducing the energy consumption and $\mathrm{CO}_{2}$ emissions of steam cracking and dehydrogenation reactions. Ryan is a founding member of the Science Policy Pack at NC State and is passionate about developing training and skill-building opportunities for early career scientists and engineers interested in science policy and advocacy.

\section{Acknowledgements}

HAH is supported by the National Science Foundation Graduate Research Fellowship Program (DGE-1746939).

\section{Disclaimer}

Authors' views do not necessarily reflect those of their respective departments or sponsors. 